\title{
Implementation of Basic Agrarian Law No. 5/1960 in Indigenous Land Disputes in Malinau District
}

\author{
Nugroho Setyawan ${ }^{1}$, Evita Isretno Israhadi ${ }^{2}$ \\ Borobudur University ${ }^{1,2}$ \\ \{nugrohosetiawan750@gmail.com¹, evita_isretno@borobudur.ac.id²
}

\begin{abstract}
This paper discusses the issue of land disputes between the two tribes who inhabit the area in the Malinau Regency. The Tidung and Lundayeh Dayak tribes often intersect over customary lands that they claim to belong to. Through a normative approach, by extracting literature data and field data, the results show that the implementation of the Basic Agrarian Law Number 5 of 1960 has not been fully able to cover and become a solution for customary land disputes in Malinau. The understanding of the apparatus that has not fully mastered the main issues of agrarian law is one of the causes of constrained implementation. Good reinterpretation and redistribution are needed to implement the Basic Agrarian Law as a solution to customary land disputes in Indonesian territory.
\end{abstract}

Keywords Dispute; Basic Agrarian Law; Indigenous Land

\section{Introduction}

The Indonesian nation consists of many tribes and languages. This cultural wealth is complemented by the many islands that geographically add to the diversity in this nation. This diversity is a blessing as well as a cultural asset that needs to be maintained and maintained. Cultural assets are characteristic and differentiating from other countries, which makes the country famous for its multiculturalism. [1] But on the other hand, this wealth needs to be maintained and maintained, as it can be a time bomb that can explode at any time. The time bomb will explode, when conflicts arise between different ethnic, ethnic, cultural and linguistic societies. Unmanaged differences will create a lot of conflict in them.

If traced back in time, the failure to manage conflicts creates a lot of friction in society. Starting from friction due to differences in religion/ beliefs, language, and much more. The conflict starts from differences in conception and paradigms that exist in society. If these differences are ignited and tapering, then conflict cannot be avoided by society. Mass media does not infrequently present conflicts that occur in the community, both on a small scale, and on a large scale. Small scale starts from conflicts between villages, to conflicts between tribes that have a national impact. The inter-tribal conflict between the Dayak and Madura tribes in Sampit, Central Kalimantan, illustrates that major conflicts between tribes can occur very severely, if diversity management is not handled properly.

Conflict between tribes due to land grabs / customary land, also occurred in the region of North Kalimantan, precisely in malinau village opposite, North Malinau District, Malinau District. Land conflict problems between indigenous peoples, as well as with companies often 
occur in Indonesia. In the period 2004 - 2015 recorded 1772 conflicts caused by land grabs, with an area of 6.9 million hectares. [2] The seizure of the territory led to a prolonged dispute. Some were successfully resolved through legal channels, but also not a little protracted until there was a tribal war. With regard to the conflict in Malinau Regency, land grabs were resolved through state law, but the settlement did not come to fruition. As a result, wars between the Tidung tribe and the Dayak Lundayeh tribe often occur.

Unitary State of the Republic of Indonesia has laws governing indigenous peoples and the rights of indigenous peoples. The 1945 Constitution article 33 states clearly that the Earth and water are controlled by the state. Further reaffirmed through the Basic Agrarian Law No. 5 of 1960 which regulates the agrarian law in which also regulates customary land and customary law that overshadows it. Related to inter-tribal conflict in Malinau Regency, how can the implementation of Agrarian Basic Law No. 5 of 1960 be used as a constructive solution? This paper discusses comprehensively the issue.

\section{Method}

This paper uses qualitative approach with normative juridical research method [3] to examine problems related to the implementation of Agrarian Basic Law No. 5 of 1960 in solving the problem of ulayat land disputes in Malinau Regency. Data derived from literature and field will be used as a tool to supplement the analytical materials. The collected data will then be analyzed descriptively and presented comprehensively. [4]

\section{Results and Discussion}

Indonesia is a country based on the law as a tool to regulate the course of its government. There are many rules of law that govern people's lives. If you look deeper, it can be examined that the law is very broad, depending on which point of view. If the law is interpreted as a normative rule, then the Law is the whole normative rule that governs and becomes a guideline of behavior in the life of society and state with the support of a certain sanctions system against any deviations against it. [5] The law in Indonesia provides a regularity in society. This includes the guarantee of indigenous peoples in carrying out customary laws in their territory. For indigenous peoples, customary law is a rule that is carried out by all members of the custom. The customary law protects both indigenous peoples, property and cultural products of the custom. One of the protected is customary land. In indigenous peoples, indigenous lands are highly protected because it concerns the identity, ancestors and territory of the customary territory. Therefore, the contact of indigenous lands becomes a conflict that often occurs in indigenous areas.

Menyadari nilai dan arti penting tanah bagi kehidupan manusia, maka para pendiri Negara Kesatuan Republik Indonesia (NKRI) merumuskan tentang tanah dan sumber daya alam secara ringkas tetapi sangat filosofis substansial di dalam Undang-undang Dasar 1945 Pasal 33 Ayat (3), yakni: "Bumi dan air dan kekayaan alam yang terkandung di dalamnya dikuasai oleh Negara dan dipergunakan untuk sebesar-besar kemakmuran rakyat". Hal ini menandakan bahwa negara memiliki tanggungjawab untuk memberikan kemakmuran kepada rakyatnya dengan melakukan pengelolaan sumber daya alam yang dimilikinya secara adil. Namun amanat tersebut nampaknya saat ini sangat jauh untuk terpenuhi sebagaimana yang diharapkan oleh sebagian besar rakyat Indonesia. 
Recognizing the value and significance of land for human life, the founders of the Unitary State of the Republic of Indonesia (NKRI) formulated about land and natural resources in a concise but very philosophical substantial in the 1945 Constitution Article 33 Paragraph (3), namely: "The earth and water and natural resources contained therein are controlled by the State and used for the greatest prosperity of the people". This indicates that the state has a responsibility to provide prosperity to its people by managing its natural resources fairly. But the mandate seems to be very far to be fulfilled as expected by most Indonesians.

For Indonesian people the inequality over land ownership is still in contrast, especially in terms of development. Where, the rapid development of the community and the increasing needs are not comparable to the land area that never increases. This inequality is in stark contrast to the lives of rural communities that are still below the poverty rate on average. This fact is inevitable because land is an economic asset in meeting the needs of the community and for the owner is also a political asset in the decision-making community. No wonder that now the land has always been a contested object that raises disputes and conflicts related to the land and resources contained in it. In addition, the inequality of the structure of control, ownership, use, and utilization of land and inequality of other production sources cause agrarian conflict.Undang-Undang Pokok Agraria tahun 1960 dalam Pasal 5 : Menyatakan bahwa, Hukum Agraria yang berlaku atas bumi, air dan ruang angkasa, ialah hukum adat. Dan dalam pasal 17 adanya pengakuan sistim kepemilikan tanah secara bersama/komunal, namun pemberlakuan hukum adat tersebut sepanjang tidak bertentangan dengan kepentingan bangsa artinya, bila kepentingan bangsa menghendaki, hukum adat dapat saja dikalahkan. Dalam hal ini perubahan masyarakat hukum adat dipengaruhi oleh politik hukum pemerintah, tanpa dipengaruhi hukum pun masyarakat akan mengalami perubahan baik secara cepat maupun secara lambat artinya tidak ada ataupun masyarakat yang statis (berhenti) pada suatu titik tertentu di dalam perkembangannya. [6]

For the people the land is seen as an eternal property because it will not be destroyed under any circumstances, in addition the land serves as a place of residence for the citizens and a place where they seek life and as a place where they will be buried if they die. Therefore, the customary land is closely related to the authority of the indigenous people itself to control the customary land (ulayat land). [7] Because the land has a multidimensional meaning for the lives of special people of agrarian society, then everyone will try to own and master it. So it is no wonder that the land becomes a special treasure and ceaselessly triggers a variety of complex and complex social problems.

According to Law No. 51/PERPU/1960, a valid land is land directly controlled by the state and land owned with a right by an individual or legal entity. The right to land ownership is the person or legal entity entitled to the land. While the right to use the land is the person who occupies, does and / or controls a piece of land or has plants or buildings on it, with no question whether the building is used alone or not. [8]

The conflict between the Tidung tribe and Dayak Lundayeh is a land boundary dispute that leads to violence. Inter-ethnic conflicts that occur in society are largely influenced by the pattern of interaction in it. In Malinau Regency, the conflict between the Tidung tribe and Dayak Lundayeh has been going on for a long time, unresolved to its roots. If investigated further, this conflict began in 2005, when the coal company PT. KPUC paves the way to the port of loading and unloading PT. KPUC. Land clearing is done by conducting land acquisition, to be made roads in the Tibu River area, which is located in malinau village, Malinau City, Malinau City. Over time, there was a land dispute involving the villagers of Kelapis Kec. Malinau Utara Kab. Malinau who claimed to be the early tenants or owners of Jakau (Jakau is a jungle land that has been cultivated or once slashed by tenants who then used 
as growing land). However, on the other hand, the land is claimed by the Tidung Customary Institution, most of whose citizens live in Malinau Village opposite North Malinau District, Malinau. The land is claimed to be inherited land from the kingdom of Tidung led by King Pandita and controlled a large area of Malinau District along the malinau river coast which is currently included in the Malinau City, North Malinau and Lower South Malinau.

As the conflict intensified, the two sides reported each other to the local government as well as to the police. In fact, both sides have done things that are considered taboo in their respective customs that triggered the tribal war, considering that both came from different tribes namely Dayak Lundayeh and Tidung. Mediation has been conducted through the relevant agencies. The mediation was conducted several times between the two sides, as well as resulting in several agreements. However, the conflict continued again because there were some parties who were dissatisfied with the mediation. At its peak, there was a shooting of one of the Tidung people while working on land in the disputed area, which was carried out by several villagers, so that the incident seemed to be the culmination of the conflict.

The peak of the conflict can be muted by the hard work and prevention of mass gathering, conducted by Bhabinkamtibmas Kelapis Village and Malinau Village opposite, and in collaboration with north Malinau Police and several Malinau Police Personnel. In the process, inter-tribal conflicts can be prevented, by means of shootings that occur in disputed areas are processed as pure criminal acts. The actions of the authorities by conducting legal proceedings against the perpetrators of the shooting in the disputed area were able to dampen the horizontal conflict between the Tidung tribe and Dayak Lundayeh. However, there is no denying that the conflict did not just disappear. Like a fire in a husk, conflict can occur if there is a small thing as a trigger. This was proven in some time, Malinau Police received reports of land invasion involving kelapis villagers with Malinau Seberang Village People. The reporting of the case is one of the indicators of conflict that exists between the Tidung tribe and Dayak Lundayeh still exists, and has not been completed by the relevant authorities through legal channels. Judging from the factual condition of the conflict that occurred between the Tidung tribe and Dayak Lundayeh, if not resolved completely, it would be a time bomb that could trigger a widespread tribal war.

Reflecting on the conflict, a good understanding of the Basic Agrarian Law No. 5 of 1960 related to indigenous peoples is required. Number 5 of 1960 related to the rights of indigenous peoples. In article 2 uupa mentioned that the earth, water, and space including the natural wealth contained in it, at the highest level controlled by the state and in paragraph (4) the article the right of control of the state can be authorized to indigenous peoples. So it is clear that ulayat institutions as the subject of state law are recognized by the UUPA. [9]

Indigenous institutions have a very important role in the settlement of land disputes. Land disputes mostly occur between indigenous peoples who defend indigenous rights to land with large capital owners who get concessions on forest control, oil mining, gas and others and agribusiness development with pir (People's Core Development) pattern. The takeover by indigenous peoples of land on which there have been productive assets has taken place in almost all regions of Indonesia. [7]

Customary institutions that guarantee customary rights such as ulayat rights authorize indigenous peoples to regulate and organize land use. This includes the authority to regulate and determine the legal relationship between the person and the land as well as the legal relationship between the person and the law relating to the land. The authority of indigenous peoples to regulate and utilize their land is often not able to be carried out as it should be because until now the existence of indigenous rights is still dilemma. On the one hand, customary rights or ulayat rights that were originally declared no longer valid still exist. On 
the other hand, customary rights or ulayat rights that are stated to exist then become lost because of pressure by the development process or by the interests of certain parties. [10]

In Law No. 5 of 1960 concerning Basic Rules of Agrarian Principles, Agrarian Candy No. 5 of 1999 concerning Guidelines for Solving The Rights of Indigenous Peoples, Letter of the Minister of Agrarian State / Head of BPN No. 400-2626 on explanation of Agrarian Permeneg / Head of BPN No. 5 of 1999 and letter of the Minister of Agrarian State / Head of BPN No. 110-201 on The Implementation of Regional Autonomy in the field of Land The Law regulates disputes related to customary land that can be resolved by customary law in the community. Disputes between tribes related to indigenous land boundaries, need to be bridged and facilitated by the state as an intermediary between conflicting communities. It is necessary to reinterpret and redistibusi the use of existing laws, so that it can be implemented to the community.

\section{Conclusion}

Conflict resolution of the illegal use of land according to the laws and regulations in Indonesia is done through mechanisms in the courts through the judiciary, through mechanisms outside the court, and utilizing customary lembags. In the court is usually done through the State Administrative Court, while outside the court is usually done through mediation, arbitration, conciliation, independent appraisal, facilitation and negotiation. Furthermore, if the form of settlement using customary institutions, then the way of settlement is done with the help of indigenous leaders and village community leaders or local community leaders such as the Village Head / Village.

\section{Reference}

[1] K. Warman, "Peta Perundang-undangan tentang Pengakuan Hak Masyarakat Hukum Adat," 2012.

[2] F. F. Busroh, "Mediasi Sosial Dalam Menyelesaikan Konflik Lahan Milik Masyarakat Adat Di Indonesia," Lex Jurnalica, no. January, 2017.

[3] I. M. P. Diantha, "Metodologi Penelitian Hukum Normatif," Teor. Metodol. Penelit. a., 2017.

[4] J. Ibrahim, "Teori dan Metode Penelitian Hukum Normatif," Bayu Media, Malang, 2006.

[5] J. Asshiddiqie, Pembentukan dan Pembuatan Hukum. Jakarta: Universitas Indonesia, 2000 .

[6] M. R. Maramis, "KAJIAN ATAS PERLINDUNGAN HUKUM HAK ULAYAT DALAM PERSPEKTIF HAK ASASI MANUSIA," vol. XXI, no. 4, pp. 98-110, 2013.

[7] I. S. MUSNITA, PENYELESAIAN SENGKETA TANAH ULAYAT MASYARAKAT MALAMOI DI KABUPATEN SORONG, vol. 3, no. 200. 2008.

[8] H. Hairan, "KEDUDUKAN TANAH ULAYAT DALAM PERSPEKTIF KONSTITUSI INDONESIA" (Undang-Undang Dasar Negara Republik Indonesia Tahun 1945)," Yuriska J. Ilm. Huk., vol. 9, no. 1, p. 38, 2017, doi: 10.24903/yrs.v9i1.44.

[9] O. C. Nugroho, "Konflik Agraria di Maluku Ditinjau dari Perspektif Hak Asasi Manusia," J. HAM, vol. 9, no. 1, p. 87, Jul. 2018, doi: 10.30641/ham.2018.9.87-101. 
[10] S. Anas, S. F. Dewi, and J. Indrawadi, "Faktor Penyebab Konflik Tanah Ulayat Antara Peladang Pendatang Vs Masyarakat Adat Di Desa Tamiai Kabupaten Kerinci," J. Sosiol. Reflektif, vol. 14, no. 1, p. 131, 2019, doi: 10.14421/jsr.v14i1.1702. 